\title{
KEBIJAKAN PEMERINTAH TERHADAP PENGALOKASIAN DANA ALOKASI UMUM DAN KETERGANTUNGAN PEMERINTAH DAERAH
}

\author{
Tri Suhendra Arbani \\ UIN Alauddin Makassar \\ tri.suhendra@uin-alauddin.ac.id
}

\begin{abstract}
Abstrak
Kebijakan pemerintah dalam mendorong desentralisasi fiskal sampai saat ini belum menunjukkan perubahan yang mendasar. Hal tersebut dapat dilihat dari besarnya transfer ke daerah dan dana desa yang setiap tahunnya terus mengalami peningkatan sehingga daerah memiliki ketergantungan yang tinggi kepada dana alokasi umum. Penelitian ini merupakan penelitian hukum dengan menggunakan pendekatan perundang-undangan dan pendekatan konsep. DAU pada dasarnya bersifat "Block Grant". Permasalahan dari melencengnya arah dan tujuan dari DAU ikut berimplikasi terhadap daerah yang hampir menggantungkan lebih dari setengah pendapatan asli daerahnya dari DAU. Setiap tahunnya dana alokasi umum seharusnya memberikan bantuan agar daerah yang kekurangan bisa terbantu. Akan tetapi, hal ini justru memberikan dampak negatif berupa ketergantungan daerah terhadap dana alokasi umum dalam memenuhi pendapatan daerahnya. Hal ini justru melenceng dari kemandirian daerah dalam mengelola dan memperoleh sumber keuangannya.

Kata Kunci: Kebijakan, DAU, Ketergantungan
\end{abstract}

\section{A. Pendahuluan}

Pemerintah daerah diharapkan agar dapat mandiri dalam berbagai aspek khususnya kemandirian di bidang fiskal. Kemandirian sangat diperlukan untuk pengembangan wilayah daerah agar tercipta desentralisasi fiskal yang baik. Permasalahan hari ini adalah kebanyakan daerah memiliki ketergantungan yang tinggi terhadap dana alokasi umum yang bersumber dari APBN. Permasalahan ini setiap tahunnya terus muncul karena ketidakmampuan daerah untuk memenuhi pandapatan dan mengatur pengeluarannya.

Kebijakan pemerintah dalam mendorong desentralisasi fiskal belum menemui titik terang pembaharuan. Hal tersebut dapat dilihat dari besarnya transfer uang kedaerah baik berupa dana perimbangan dan dana desa yang setiap tahunnya terus mengalami peningkatan. Jika melihat peningkatan 
alokasi dari tahun 2014 sampai tahun 2018 mengalami peningkatan sebesar 32,09 persen, tahun 2014 sebanyak Rp. 573,7 Trilliun dan di tahun 2018 menjadi Rp. 757,8 Trilliun. Dari alokasi tersebut maka rata-rata peningkatan pertahun mencapai 8,2 persen. Adapun komponen utama yang menyebabkan kenaikan alokasi daerah tersebut adalah peningkatan dari Dana Alokasi Umum dengan rata-rata porsinya pertahun sebesar 55,4 persen. ${ }^{1}$

Ketergantungan daerah dalam bidang keuangan atau fiskal terhadap alokasi pusat justru lebih parah terjadi di tingkat pemerintah kota/kabupaten. Fakta ini sangat sulit untuk dipungkiri karena kabupaten/kota memang sangat menggantungkan sumber pendapatan daerah dari Dana Alokasi Umum. Padahal untuk kabupaten/kota inilah titik berat dari otonomi daerah dan desentraliasi fiskal yang telah dinyatakan dalam undang-undang perimbangan keuangan antara pemerintah pusat dan daerah. ${ }^{2}$ Kebijakan perimbangan keuangan bertujuan agar daerah yang tingkat pendapatannya rendah dapat diberikan keadilan dari segi fiskal. Keuangan daerah merupakan aspek terpenting dan menjadi urat nadi dari aktifitas pemerintahan daerah ${ }^{3}$

Kebijakan transfer ke daerah ini pada dasarnya bertujuan dalam mengurangi ketimpangan fiskal di berbagai daerah melalui DAU dan Dana Alaokasi Khusus atau (DAK). Mengenai DAU, pada proses penyalurannya berperan untuk terhadap pendistribusian dari pemerintah ke pemerintah daerah yang ditujukan agar mengurangi ketimpangan keuangan antar daerah. ${ }^{4}$ Pada pengertian dari Undang-Undang Nomor 33 Tahun 2004 dapat dijelaskan bahwa DAU adalah salah satu solusi untuk menghadapi tantangan terhadap ketimpangan fiskal terhadap satu daerah dengan daerah lainnya. Dari tujuan diatas yang merupakan dasar dari pengalokasian DAU setiap tahunnya yang bersumber dari Anggaran pendapatan belanja Negara (APBN).

${ }^{1}$ Edi Suwiknyo, https://ekonomi.bisnis.com/read/20190528/9/928193/desentralisasi-fiskalbelum-optimal-ketergantungan-daerah-ke-pusat-masih-tinggi, diakses pada tanggal 01 Desember 2019.

${ }^{2}$ Yoga Nurdiana Nugraha, https://www.kemenkeu.go.id/publikasi/artikel-danopini/ketergantungan-fiskal-daerah-dalam-pelaksanaan-desentralisasi-fiskal-di-indonesia/, diakses pada tanggal 12 November 2019

${ }^{3}$ Tri Suhendra Arbani, "Penggunaan dan Batas Diskresi Dalam Pengelolaan Keuangan Daerah Di Indonesia." Widya Pranata Hukum: Jurnal Kajian Dan Penelitian Hukum , 1.2 2019, hlm. 177.

${ }^{4}$ Pasal 1 angka (21) Undang-Undang Nomor 33 Tahun 2004 tentang perimbangan Pusat dan Daerah, Lembaran Negara Republik Indonesia Tahun 2004 Nomor 126, Tambahan Lembaran Negara Republik Indonesia Nomor 4438. 
Dana alokasi umum setiap tahunnya ditetapkan sekurang-kurangnya 26 $\%$ (dua puluh enam persen) terhadap pendapatan dalam negeri neto yang ditetapkan dalam APBN. Adapun untuk pembagian porsi DAU untuk provinsi dan kabupaten/kota ditetapkan sesuai dengan imbangan dari kewenangan antara provinsi dan kabupaten/kota. DAU pada dasarnya bersifat "Block Grant" yang pada intinya pengelolaan diserahkan kepada emerintah daerah dengan menyesuaikan prioritas dari setiap daerah. Hal ini bertujuan untuk peningkatan pelayanan kepada masyarakat dan peningkatan otonomi daerah. Penghitungan untuk DAU dihitung berdasarkan pendekatan celah fiskal (Fiskal Gap) yakni selisih antara kebutuhan fiskal (Fiskal Needs) dikurangi dengan kapasitas fiskal (Fiskal Capacity) daerah dan alokasi dasar (AD) berupa jumlah gaji PNS.

Permasalahan dari melencengnya arah dan tujuan dari DAU ikut berimplikasi terhadap daerah yang hampir menggantungkan lebih dari setengah pendapatan asli daerahnya dari DAU. Hal ini tidak terlepas dari peran dan kebijakan pemerintah dan pemerintah daerah dalam mengontol tujuan dari DAU. Kondisi di atas menyisakan beberapa pertanyaan seperti apakah kebijakan desentralisasi fiskal diberbagai daeah sudah benar-benar efektif dan mengapa sampai saat ini masih banyak daeah yang terlalu menggantungkan sebagian besar pendapatan daerahnya justu dari DAU? Dari masalah inilah yang akan menjadi bahan kajian untuk menjawab permasalahan yang ada.

\section{B. Hasil dan Pembahasan}

\section{Kebijakan Dana Alokasi Umum sebagai Wujud Keadilan Finansial Daerah}

Konsep desentraliasi di Indoenesia menganut desentralisasi yang beragam. Desentralisasi dengan segala bentuknya yang telah membawa bangsa dan negara Republik Indonesia dalam suasana yang memungkinkan daerah untuk mengatur dan mengurus kepentingan daerahnya sesuai dengan aspirasi yang hidup dan berkembang dalam masyarakat.

Konsep desentraliasi dalam hal ini adalah otonomi dalam tataran teori maupun prakteknya tidak serta merta dapat dipisahkan dari persoalan yang berhubungan dengan keuangan atau finansial. Otonomi dalam perspektif Undnag-Undang Nomor 33 Tahun 2004 tentang Perimbangan Keuangan Pusat dan Daerah diklasifikasikan sebagai hak, wewenang, dan kewajiban untuk mengatur dan mengurus sendiri urusan pemerintahan dan kepentingan masyarakat setempat, mengandung makna bahwa hak, 
wewenang serta kewajba tersebut untuk "membiayai" atau Bagir Manan menggunakan istilah "membalanjai" diri sendiri.

Rangka membiayai penyelenggaraan aktivitas pemerintahannya, daerah harus mempunyai sumber-sumber pendapatan sendiri, baik karena adanya penyerahan urusan wewenang oleh pemerintah pusat kepada daerah seperti pajak dan retribusi daerah maupun sumber-sumber pendapatan yang secara turun menurun memang telah dikelola dan diurus oleh daerah.

Penyerahan suber-sumber keuangan kepada daerah oleh pemerintah pusat sangat erat kaitannya dengan penyerahan urusan pemerintah kepada daerah sebagai konsekuensi dianutnya asas desentraliasi. Oleh karena itu, sumber-sumber keuangan yang diserahkan kepada daerah mestinya sebanding dengan tugas dan tanggung jawab yang diserahkan kepada daerah untuk mengatur dan mengurus urusan pemerintahan. Dengan perkataan lain, perimbangan keuangan harus menunjukkan bahwa penyerahan urusan-urusan pemerintahan yang menjadi wewenang daerah mencerminkan adanya keseimbangan dengan penyerahan pengelolaan dan pemanfaatan sumber-sumber keuangan yang ada di daerah. ${ }^{6}$

Selain itu, pemeritah daerah juga harus memiliki kemapuan dalam menentukan secara obyektif berbagai kebutuhan keuangan (fiscal need) yang diperlukan untuk membiayai penyelenggaraan dan menyediakan pelayanan yang diperlukan masyarakat daerah. Artinya, pemerintah daerah harus dapat melakukan perhitungan-perhitungan yang matang dan rasional mengenai rencana kegaiatan-kegiatan yang akan dilaksanakn sehubungan dengan penyerahan urusan pemerintahan kepada daerah, berdasarkan rencana kegiatan tersebut, pemerintah daerah harus dapat menentukan secara tepat dan objektif rencana pembiayaan masing-masing kegiatan, sehingga akan diketahui kebutuhan keuangan (fiscal need) yang diperlukan dalam satu tahun anggaran. Pemerintah pusat harus secara cermat dalam menentukan dan melihat besarnya subsidi harus didasarkan pada pertimbangan-pertimbangan yang dapat diterima oleh daerah penerima subsidi. Kebutuhan keuangan daerah juga harus dikaji kembali berdasarkan hlm. 204.

${ }^{5}$ Bagir Manan, 2004, Menyongsong Fajar Otonomi Daerah, PSH FH UII, Yogyakarta,

${ }^{6}$ Tri Suhendra Arbani, Analisis Dampak Kebijakan Pemerintah Tentang Penundaan Sebagian Dana Alokasi Umum Tahun 2016 Di Kabupaten Pangkep. diss. Universitas Gadjah Mada, 2018, hlm 2. 
kebutuhan rill dari suatu daerah karena kebutuhan tersebut bisa saja melebihi dari kebutuhan dasarnya.

Secara normatif, keterlibatan masyarakat dalam menentukan besarnya prosentase dana yang berasal dari DAU telah diwakili oleh wakil mereka yang berada pada lembaga Dewan Perwakilan Rakyat (DPR) sebagai representasi rakyat. Disamping itu berdasarkan ketentua Pasal 22 D ayat (2) UUD 1945 yang berisi bahwa Dewan Perwakilan Daerah ikut membahas rancangan undang-undang yang berkaitan dengan otonomi daerah; hubungan pusat dan daerah; pembenutukan, pemekaran, dan penggabungan daerah; pengelolaan sumber daya alam dan sumber daya ekonomi lainnya, serta perimbangan keuangan pusat dan daerah yang diajukan oleh DPR maupun pemerintah. Memperhatikan hal tersebut, maka setiap pembahasan sebuah RUU baik yang berasal dari pemerintah maupun RUU inisiatif DPR yang substansinya mengatur kepentingan daerah, keterlibatan DPD merupakan suatu keharusan yang diatur oleh UUD 1945. ${ }^{7}$ Ketika kembali pada awal pembentukan Undang-Undang Nomor 33 Tahun 2004 tentang Perimbangan Keuangan Pemerintah Pusat dan Daerah sama sekali tidak melibatkan DPD. Sedangkan d isisi lain hal ini tentu dapat dimaklumi karena waktu proses pembahasan Undang-Undang tersebut, lembaga DPD belum terbentuk. Walaupun pada saat itu DPD memang belum terbentuk akan tetapi tetap harus menjadi pertimbangan keterlibatan DPD dalam pembahasan teknis penganggaran dan kebijakan formula DAU yang daitur setiap tahunnya

Pengaturan dan pengambilan kebijakan dana alokasi umum sudah harus mempertimbangkan berbagai aspek mengikuti dinamika dari pemerintahan daerah saat ini. Dilihat dari segi regulasi sendiri, pengaturan dana perimbangan pusat dan daerah khususnya dana alokasi umum sudah harus ditinjau kembali. Peninjajuan kembali regulasi dikarenakan karena banyaknya kelemahan dan ketidakmampuan mengukuti perkembangan dari daerah.

Kelemahan dari regulasi dari dana alokasi umum bisa dilihat dari berbagai aspek seperti pengaturan tentang penghitungan, pengalokasian serta penetapan berdasarkan wilayahnya. Aspek dana alokasi umum yang sekarang tidak mengikuti perkembangan adalah penetapan dana alokasi

${ }^{7}$ Bahrul Elmi, 2002, Keuangan Pemerintah Daerah Otonomi di Indonesia, UI-Press, Jakarta, hlm. 60 . 
umum berdasarakan wilayah pesisir dan kepulauan. Salah satu daerah pesisir dan kepulauan memiliki daerah geografis dan penyebaran penduduk yang menyebar keberbagai pulau. Hal ini tentu bisa menjadi pertimbangan dalam penghitungan ke depannya dana alokasi umum.

Hal lain yang perlu diperhatikan adalah mengenai penghitungan dana transfer DAU ke daerah seperti kabupaten yang lebih tinggi tingkat lobinya dari pada penghitungan rill yang sesuai dengan fakta lapangan. Banyaknya kasus kepala daerah yang melakukan suap untuk melobi kepusat untuk pengalokasian dana alokasi umum meningkat dari tahuntahun sebelumnya.

Dari masalah inilah yang kedepannya perlu disempurnakan kembali dari segi regulasi dan kebijakan sehingga kelemahan-kelamahan di atas bisa diperkuat kembali. Masalah tersebut yang menjadi celah dari daerah yang menggantungkan pendapatan daerahnya dari pendapatan daerah yang bersumber dari dana alokasi umum.

Pola hubungan keuangan antara pusat dan daerah dimasa yang akan datang dalam tata penyelenggaraan pemerintahan di Indonesia harus dapat $\operatorname{menjamin}^{8}$ :

a. Pendistribusian kewenangan yang adil dan rasional antara pemerintah Pusat dan Daerah dalam hal memungut dan menggunakan sumbersumber pendapatan pemerintah;

b. Pembagian yang adil dan memadai di antara pemerintah daerah yang satu dengan yang lainnya atas sumber-sumber pendapatan dalam rangka pelaksanaan fungsi-fungsi pemerintahan, pelayanan umum dan pembangunan;

c. Kemandirian daerah dalam menentukan cara mengatur dan mengurus kepentingan masyarakat dan daerah yang bersangkutan;

d. Keterlibatan segenap komponen masyarakat daerah dalam menentukan besarnya distribusi dana perimbangan maupun dana bagi hasil, serta dalam menentukan kriteria atau variabel yang akan dipergunakan sebagai rumus penentuan besarnya dana bantuan dari pemerintah pusat, hal tersebut merupakan pecerminan pelaksanaan prinsip dmokrasi dalam penyelenggaraan pemerintahan daerah yang merupakan konsekuensi negara kesatuan yang didesentralisasikan;

\footnotetext{
${ }^{8}$ Ibid., hlm. 299-300.
} 
e. Spesific grants atau DAK diarahkan untuk pemberian insentif kepada pemerintah daerah untuk turut mensukseskan program-program nasional yang bersifat prioritas;

f. General grants (DAU) maupun revenue sharing (DBH) diarahkan untuk penciptaan keseimbangan fiskal baik vertikal maupun horizontal.

Regulasi yang ada sekarang yang mengatur dana alokasi umum berdasarkan Undang-Undang Nomor 33 Tahun 2004 tentang Dana Perimbangan Keuangan Pusat dan Daerah, dan Undang-Undang Nomor 17 Tahun 2003 tentang Keuangan Negara serta peratuan lainnya yang mengatur mengenai pembagian dana transfer ke daerah. Sudah saatnya pengaturan dan kebijakan dana alokasi umum bisa dikaji kembali agar bisa mengikuti perkembangan dan dinamika daerah. Walaupun pada asas perundang-undangan dinyatakan bahwa undang-undang sudah ketinggalan setelah dia disahkan, akan tetapi dengan memperbaharui atau merubah kembali setidaknya membuka ruang untuk penyempurnaan kembali dari segi regulasi dan kebijakan.

\section{Ketergantungan Pemerintah Daerah terhadap Dana Alokasi Umum (DAU)}

Pemerintah Daerah diberikan kemadirian untuk mengembangkan dan membangun lingkup daerahnya masing-masing. Kemandirian inilah yang menjadi tujuan utama dari konsep desentralisasi di Indonesia. Pembangunan daerah memerlukan peningkatan sumber daya manusia dan pendapatan yang cukup.

Pendapatan daerah bisa didapatkan dari berbagai aspek salah satunya dari pendapatan asli daerah (PAD), dana perimbangan pusat dan daerah serta pendapatan lainnya yang sah. Pada pendapatan asli daerah, Pendapatan asli daerah merupakan pendapatan yang diperoleh oleh daerah yang dipungut berdasarkan peraturan daerah sesuai dengan pertauran perundang-undangan yang berlaku. ${ }^{9}$ Pendapatan daerah lainnya yang bersumber dari dana perimbangan adalah dari dana alokasi umum.

Pendapatan daerah yang bersumber dari dana perimbangan yang merupakan dana transfer pusat ke daerah. Transfer pemerintah pusat ke daerah melalui dana perimbangan diperkirakan akan mereduksi peranan dari pengelolaan fiskal pemerintah pusat, hal sebaliknya akan dirasakan

${ }^{9}$ Pasal 1 Angka 18 Undang - Undang Nomor 33 Tahun 2004 tentang Perimbangan Keuangan Antara Pemerintah Pusat dan Pemerintah Daerah. 
oleh pemerintah daerah dimana proposisi total pengeluaran pemerintah daerah melalui APBD akan meningkat tajam. Pergeseran pengelolaan fiskal dari pemerintah pusat ke daerah pada umumnya akan berdampak pada peningkatan pemerintah daerah dalam melaksanakan pelayanan umum kepada masyarakat serta mengatur dan mengurus rumah tangga pemerintah daerah itu sendiri. ${ }^{10}$

Setiap tahunnya dana alokasi umum seharusnya memberikan bantuan agar daerah yang kekurangan bisa terbantu. Akan tetapi hal ini justru memberikan dampak negatif berupa ketergantungan daerah terhadap dana alokasi umum dalam memenuhi pendapatan daerahnya. Hal ini justru melenceng dari kemandirian daerah dalam mengelola dan memperoleh sumber keuangannya. Ironisnya lagi dominasi transfer dari pusat tidak diikuti dengan perbaikan pengelolaannya (governance). Riset empiris Bank Dunia (2001) menunjukkan tingginya ketergantungan pada transfer berbanding terbalik dengan governansinya. Maksudnya, pemerintah daerah akan lebih berhati-hati dalam mendayagunakan PAD daripada dana transfer yang diterima dari pusat. ${ }^{11}$

Data tersebut memberikan gambaran bahwa besarnya tingkat ketergantungan daerah terhadap kebutuhan keuangannya. Diperlukan suatu kebijakan dan regulasi yang menjadi dasar sehingga daerah sudah harus mandiri secara fiskal atau keuangan ke depannya.

Besarnya tingkat ketergantungan daerah di Indonesia, terdapat beberapa penyebabnya seperti

a. tingginya tingkat derajat sentralisasi dalam bidang perpajakan, dan pajak yang diperoleh daerah sangat rendah;

b. kurang berperannya badan usaha milik daerah sehingga pendapatan daerah juga kurang maksimal;

c. ketergantungan fiskal yang bersumber dari perkembangan penduduk tidak diikuti dengan peningkatan penerimaan negara;

d. terdapatnya persaingan antar pemerintah daerah dalam hal persaingan pajak (tax competition) antar daerah;

${ }^{10}$ Hendra Kusuma, Desentralisasi Fiskal dan Pertumbuhan Ekonomi di Indoenesia, Jurnal Ekonomi Kuantitatif Terapan Vol.9 No. 1, hal. 2.

${ }^{11}$ Yoga Nurdiana Nugraha, https://www.kemenkeu.go.id/publikasi/artikel-danopini/ketergantungan-fiskal-daerah-dalam-pelaksanaan-desentralisasi-fiskal-di-indonesia/, diakses pada tanggal 12 November 2019. 
e. peningkatan DAU sering dipersepsikan dengan peningkatan tanggungjawab yang dibebankan pemerintah kepada pemerintah daerah.

f. kekhawatiran daerah yang memiliki sumber keuangan tinggi, karena hal tersebut justru akan mendorong terjadinya disintegritas dan separatisme.

Selain masalah itu, daerah tidak memberikan data yang sesungguhnya terkait tingkat kebutuhan fiskalnya atau fiskal need. Sehingga kebutuhan daerah sengaja ditingkatkan agar bisa tertutupi melalui dana alokasi umum. Perbaikan dan solusi kedepannya sangat diperlukan sehingga ketergantungan daerah terhadap kebutuhan dana alokasi umum bisa diatasi dan mewujudkan kemandirian secara fiskal baik terhdapa pengelolaan dan mencari sumber keuangannya.

Adapun solusi kedepannya sebagaimana yang dikatakan oleh Yoga Nurdina N, seperti: pertama perbaikan regulasi dan formulasi kebijakan di bidang pendapatan daerah melalui pengemabangan pajak dan retribusi daerah yang bisa menyesuaikan dengan pajak pusat. Kedua pemerintah daerah melakukan analisis kinerja dengan menggunakan Balance Scorecard yang berarti analisis kinerja dengan menggunakan empat dimensi pengukuran seperti segi keuangan, operasi internal, perspektif konsumen serta inovasi. Ketiga kebijakan produktifitas tenaga kerja juga perlu lebih diterapkan agar dapat menyeimbangkan kebutuhan keuangan tau fiskal dengan menyesuaikan kemampuan transfer pemerintah melalui peningkatan penerimaan pajak. Keempat penetapan kebijakan mengenai standar tariff pajak yang layak agar penurunan tariff pajak tidak berada dibawah batas yang telah ditentukan, juga mengajak pemerintah daerah untuk ikut bersama melakukan perubahan. Kelima pemerintah menetapkan sistem reward and punishment kepada daerah yang tidak taat terhadap pengelolaan dana daerahnya. Terakhirnya perlu pemahaman mendasar secara umum kepada masyarakat, dan secara khusus kepada pemimpin daerah dengan konsep desentralisasi. ${ }^{12}$

Adapun beberapa hal yang harus dicermati dan dijadikan sebagai langkah penyempurnaan dalam pelaksanaan perimbangan keuangan dan

\footnotetext{
${ }^{12}$ Ibid.
} 
hubungan pusat antara pemerintah pusat dan daerah, adalah sebagai berikut $^{13}$ :

a. Dalam pelaksanaan desentraisasi fiskal perlu dipikirkan adanya semacam pedoman dari pemerintah pusat sebagai sarana pengawasan;

b. Prinsip money follow function harus dilaksanakan secara konsisten sehingga kewenangan harus ditetapkan terlebih dahulu baru kemudian menetapkan dan mentransfer dana yang diperlukan;

c. Desentralisasi fiskal harus mempertimbangkan kebijakan fiskal khususnya unutk mendukung kebijakan makro ekonomi antara lain yang berkaitan dengan fisca sustainbility dan tetap memberikan ruang bagi pemerintah pusat unutk mengadakan koreksi atas ketimpangan antara daerah dengan DAK;

d. Dengan gambaran consolidatied reveues (APBD Kabupaten/Kota + Propinsi + Penerimaan dana dalam negeri APBN), Porsi Pendapatan Asli Daerah (PAD) hanya 3,45 \% tergolong sangat sentralistis. Untuk itu perlu diupayakan meningkatkan taxing powers daerah antara lain melalui penyerahan beberapa pajak pusat dan daerah, penyerahan sebagian PNBP kepada daerah, dan lain-lain kebijakan sharing tax atau piggi backing system. Kebijakan ini sekaligus untuk menghilangkan upaya daerah untuk menggali sumber-sumber PAD yang berdampak distortif terhadap perekonomian;

e. Pemberian kewenangan pelayanan publik kepada daerah yang semakin besar tetap mempertimbangkan expendenture efficient principles;

f. Terdapat keseimbangan antara akuntabilitas dan kewenangan dalam melakukan melakukan pungutan pajak dan retribusi daerah (taxing powers) sehingga penyimpangan penggunanan anggaran daerah dapat diperkecil atau bahkan ditiadakan;

g. Pemerintah pusat harus tetap mempertahankan komitmennya terhadap pelaksanaan desentralisasi dengan mematuhi perundang-undangan yang berlaku sehingga kegiatan-kegiatan dalam rangka desentralisasi sepenuhnya kewenangan yang diberikan kepada daerah;

h. Bantuan pemerintah pusat yang berbentuk general grants atau DAU maupun reveneu sharing (bagi hasil) diarahkan untuk : (a) penciptaan keseimbangan fiskal baik vertikal maupun horizontal;

\footnotetext{
${ }^{13}$ Hendra Kusuma, Loc. Cit.
} 
menumbuhkan insentif bagi pemerintah daerah dalam melaksanakan segala fungsi/kesenangan yang menjadi tanggungjawabnya;

i. Sementra untuk spesific grants atau DAK diarahkan untuk pemberian insentif kepada pemerintah daerah untuk turut mensukseskan programprogram nasional yang bersifat prioritas;

j. Konsep perhitungan DAU harus mengacu pada konsep fiscal gap (kebutuhan daerah-kapasitas daerah), kebutuhan daerah diukur dengan pendekatan pengukuran standart Pelayanan Minimal (SPM) dan Standart Analisis Belanja (SAB) masing-masing daerah.

Dari penjelasan tersebut memberikan pandangan mengenai langkah penyempurnaan dalam pelaksanaan perimbangan keuangan dan hubungan pusat antara pemerintah pusat dan daerah. Khusus pada aspek Dana Alokasi Umum DAU, diperlukan juga berbagai perubahan mendasar untuk mengatasi masalah-masalah yang ada kedepannya. Diatas telah dibahas bahwa bantuan pemerintah pusat yang berbentuk general grants atau DAU maupun reveneu sharing (bagi hasil) diarahkan untuk: (a) penciptaan keseimbangan fiskal baik vertikal maupun horizontal; (b) menumbuhkan insentif bagi pemerintah daerah dalam melaksanakan segala fungsi/kesenangan yang menjadi tanggungjawabnya. ${ }^{14}$

\section{Kesimpulan}

DAU pada dasarnya bersifat "Block Grant" yang berarti penggunaannya diserahkan kepada daerah sesuai dengan prioritas dan kebutuhan daerah dalam rangka peningkatan pelayanan kepada masyarakat dan peningkatan otonomi daerah. Permasalahan dari melencengnya arah dan tujuan dari DAU ikut berimplikasi terhadap daerah yang hampir menggantungkan lebih dari setengah pendapatan asli daerahnya dari DAU. Hal ini tidak terlepas dari peran dan kebijakan pemerintah dan pemerintah daerah dalam mengontol tujuan dari DAU.

Setiap tahunnya dana alokasi umum seharusnya memberikan bantuan agar daerah yang kekurangan bisa terbantu. Akan tetapi hal ini justru memberikan dampak negatif berupa ketergantungan daerah terhadap dana alokasi umum dalam memenuhi pendapatan daerahnya. Hal ini justru melenceng dari kemandirian daerah dalam mengelola dan memperoleh sumber keuangannya. Ironisnya lagi dominasi transfer dari pusat tidak diikuti dengan

${ }^{14}$ Ibid. 
perbaikan pengelolaannya (governance). tingginya tingkat derajat sentralisasi dalam bidang perpajakan, dan pajak yang diperoleh daerah sangat rendah: kurang berperannya badan usaha milik daerah sehingga pendapatan daerah juga kurang maksimal, ketergantungan fiskal yang bersumber dari perkembangan penduduk tidak diikuti dengan peningkatan penerimaan negara, terdapatnya persaingan antar pemerintah daerah dalam hal persaingan pajak (tax competition) antar daerah, peningkatan DAU sering dipersepsikan dengan peningkatan tanggungjawab yang dibebankan pemerintah kepada pemerintah daerah, kekhawatiran daerah yang memiliki sumber keuangan tinggi, karena hal tersebut justru akan mendorong terjadinya disintegritas dan separatisme. Selain masalah itu, daerah tidak memberikan data yang sesungguhnya terkait tingkat kebutuhan fiskalnya atau fiskal need.

\section{Saran}

Perlu disempurnakan kembali dari segi regulasi dan kebijakan sehingga kelemahan - kelemahan dari dana alokasi umum bisa diperkuat kembali ke depannya. Khususnya masalah yang menjadi celah dari daerah yang menggantungkan pendapatan daerahnya dari pendapatan daerah yang bersumber dari dana alokasi umum. Regulasi atau kebijakan haruslah melihat perkembangan dan kebutuhan dari daerah seperti pembagian perhitungan dana alaikasi umum yang melihat sisi geografis sperti wilayah pesisir dan kepulauan.

Adapun solusi ke depannya sebagaimana yang dikatakan oleh Yoga Nurdina N, seperti: pertama perbaikan regulasi dan formulasi kebijakan di bidang pendapatan daerah melalui pengemabangan pajak dan retribusi daerah yang bisa menyesuaikan dengan pajak pusat. Kedua pemerintah daerah melakukan analisis kinerja dengan menggunakan Balance Scorecard yang berarti analisis kinerja dengan menggunakan empat dimensi pengukuran seperti segi keuangan, operasi internal, perspektif konsumen serta inovasi. Ketiga kebijakan produktifitas tenaga kerja juga perlu lebih diterapkan agar dapat menyeimbangkan kebutuhan keuangan tau fiskal dengan menyesuaikan kemampuan transfer pemerintah melalui peningkatan penerimaan pajak. Keempat penetapan kebijakan mengenai standar tarif pajak yang layak agar penurunan tariff pajak tidak berada di bawah batas yang telah ditentukan, juga mengajak pemerintah daerah untuk ikut bersama melakukan perubahan. Kelima pemerintah menetapkan sistem reward and punishment kepada daerah yang tidak taat terhadap pengelolaan dana daerahnya. Terakhir perlu 
pemahaman mendasar secara umum kepada masyarakat, dan secara khusus kepada pemimpin daerah dengan konsep desentralisasi.

\section{Daftar Pustaka}

\section{Buku:}

Elmi, Bahrul, 2002, Keuangan Pemerintah Daerah Otonomi di Indonesia, UIPress, Jakarta.

Manan, Bagir, 2004, Menyongsong Fajar Otonomi Daerah, PSH FH UII, Yogyakarta.

Arbani, Tri Suhendra, 2018, Analisis Dampak Kebijakan Pemerintah Tentang Penundaan Sebagian Dana Alokasi Umum Tahun 2016 di Kabupaten Pangkep. Universitas Gadjah Mada, Yogyakarta.

\section{Jurnal:}

Kusuma, Hendra Desentralisasi Fiskal dan Pertumbuhan Ekonomi di Indonesia, Jurnal Ekonomi Kuantitatif Terapan, Vol. 9, No. 1.

Arbani, Tri Suhendra, 2019, "Penggunaan dan Batas Diskresi Dalam Pengelolaan Keuangan Daerah Di Indonesia", Widya Pranata Hukum: Jurnal Kajian dan Penelitian Hukum.

\section{Peraturan Perundang - Undangan:}

Undang-Undang Nomor 33 Tahun 2004 tentang perimbangan Pusat dan Daerah, Lembaran Negara Republik Indonesia Tahun 2004 Nomor 126, Tambahan Lembaran Negara Republik Indonesia Nomor 4438.

\section{Website:}

Edi Suwiknyo, https://ekonomi.bisnis.com/read/20190528/9/928193/desentralisasifiskal-belum-optimal-ketergantungan-daerah-ke-pusat-masih-tinggi, diakses pada tanggal 01 Desember 2019.

Yoga Nurdiana Nugraha, https://www.kemenkeu.go.id/publikasi/artikel-danopini/ketergantungan-fiskal-daerah-dalam-pelaksanaan-desentralisasifiskal-di-indonesia/, diakses pada tanggal 12 November 2019. 